\title{
Two novel anticancer compounds with minimum cardiotoxic property
}

\author{
Tayebeh Afsharirad ${ }^{1,2+}$, Raheleh Tahmasvand ${ }^{2 \dagger}$, Mohsen Amini ${ }^{3}$, Bahram Daraei ${ }^{1}$ and Mona Salimi ${ }^{2 *}$
}

\begin{abstract}
Background: Although two novel synthesized compounds with tri-aryl structures; 3-(4-chlorophenyl)-5-(4fluorophenyl)-4-phenyl-4,5-dihydro-1,2,4-oxadiazole (A) and 3,5-bis-(4-chlorophenyl)-4-phenyl-4,5-dihydro-1,2,4oxadiazole (B) have been previously demonstrated to possess remarkable anti-breast cancer activity, their cardiotoxicity remains a major concern due to their mechanism of action. To address this concern, we assessed the ability of these compounds to cause toxicity towards $\mathrm{H} 9 \mathrm{c} 2$ cardiomyocytes as an in vitro model of cardiotoxicity.

Methods: Cytotoxic activity of both compounds was explored in vitro on H9c2 cells using MTT assay. Annexin V/PI method, intracellular ROS determination and mitochondrial membrane potential assay were applied to elucidate the mechanism of action of the cell death.

Results: MTT assay revealed a concentration- and time-dependent cardiotoxicity. Findings of apoptosis by double staining with annexin $V$ and propidium iodide divulged no cell death including apoptosis and necrosis at the concentration that were effective to inhibit cancer cells proliferation $(10 \mu \mathrm{M})$ at 24 and $48 \mathrm{~h}$. Furthermore, flow cytometric measurement of membrane potential and ROS determination using DCFH-DA verified the safe concentration of the compounds against H9c2 cells with no cardiotoxic effect. However, the higher concentration of the compounds could induce cell death through ROS-mediated mitochondrial dysfunction.
\end{abstract}

Conclusions: Altogether, the results represented two novel chemical molecules possessing anti-breast cancer activity with minimum cardiac side effect.

Keywords: Cardiotoxicity, Apoptosis, ROS, Mitochondrial potential

\section{Background}

Cardiovascular diseases (CVDs) remains number one of the fatal diseases, which is ever increasing worldwide and hence, scientific community has concerned about it $[1,2]$. Cardiotoxicity occurs as a result of the complicated working of cardiac cells and tissues or due to a chemical molecule affecting heart function and structure $[3,4]$. Cardiotoxicity induced by drugs has gained attention in the past few decades. In this context, anticancer

\footnotetext{
* Correspondence: salimi_mona@yahoo.com

${ }^{\dagger}$ Tayebeh Afsharirad and Raheleh Tahmasvand contributed equally to this work.

${ }^{2}$ Physiology and Pharmacology Department, Pasteur Institute of Iran, P.O. Box 13164, Tehran, Iran

Full list of author information is available at the end of the article
}

therapy has a direct impact on cardiac function and the most common toxicities of heart are due to cancer treatment [5]. However, clinicians still use many cardiotoxic drugs due to their beneficial effects, which outweigh cardiac malformations risks [4]. As it was above-mentioned, most of the anticancer drugs exhibit a wide range of cardiovascular toxicities which results in stopping cancer treatment and affects the short- and long-term quality of life [6-8].

Inflammation and oxidative stress are mutually reliant processes, which predominantly involve in cardiovascular diseases and cancers via inducing apoptosis and necrosis [9-13]. In other words, high level of reactive oxygen species (ROS) due to oxidative stress can enfeeble cardiac cellular signaling pathways [14].

(c) The Author(s). 2020 Open Access This article is licensed under a Creative Commons Attribution 4.0 International License, which permits use, sharing, adaptation, distribution and reproduction in any medium or format, as long as you give appropriate credit to the original author(s) and the source, provide a link to the Creative Commons licence, and indicate if changes were made. The images or other third party material in this article are included in the article's Creative Commons licence, unless indicated otherwise in a credit line to the material. If material is not included in the article's Creative Commons licence and your intended use is not permitted by statutory regulation or exceeds the permitted use, you will need to obtain permission directly from the copyright holder. To view a copy of this licence, visit http://creativecommons.org/licenses/by/4.0/ The Creative Commons Public Domain Dedication waiver (http://creativecommons.org/publicdomain/zero/1.0/) applies to the data made available in this article, unless otherwise stated in a credit line to the data. 
Triaryl template-based structures found in a wide array of compounds, display various biological properties including anticancer $[15,16]$. Besides it, a number of compounds with this pivotal structural feature revealed cyclooxygenase-2 (COX-2) inhibitory activity [17]. In this line, we previously reported the apoptotic activity of the two compounds; 3-(4-chlorophenyl)-5-(4-fluorophenyl)-4-phenyl-4,5-dihydro-1,2,4-oxadiazole (A) and 3,5bis-(4-chlorophenyl)-4-phenyl-4,5-dihydro-1,2,4-oxadiazole (B) (Fig. 1) in the breast cancer cells via a COX-2 independent pathway [18], although these compounds interacted with the active site of COX-2 enzyme [19]. Notably, different hypothesis were raised by researchers for the discernible increase in cardiotoxicity due to apoptosis in the terminally differentiated cardiomyocytes [20]. Interestingly, amongst different pathophysiological consequences, cardiovascular diseases are associated with apoptosis. Indeed, a number of studies provided convincing evidence that cardiac cell death has been contributed to major heart diseases including myocardial infarction (MI), cardiomyopathies, arrhythmogenic right ventricular dysplasia, end-stage heart failure, etc. [21-23].

Given the importance of cardiac cell apoptosis and knowing that major mechanism related to the two tested compounds is triggering mitochondrial apoptosis, motivated us to evaluate the cardiotoxicity of the compounds. Since generation of ROS activates mitochondrial-mediated apoptotic signaling pathway leading to caspase 3 activation and cardiac cell apoptosis, we further focused on the understanding of molecular mechanism underlying cardiotoxicity of two compounds. To achieve it, a cell culture model created by rat cardiomyoblast cell line (H9c2) was applied.

\section{Materials and methods}

\section{Cell culture}

H9c2 (Rat embryonic cardiac myoblast) cell line (C585) was obtained from National Cell Bank of Pasteur
Institute of Iran. The cells were cultured in Dulbecco's Modified Eagle's Medium (DMEM) (Gibco-BRL, Rockville, IN) containing high level of glucose and $2 \mathrm{mM} \mathrm{L-}$ glutamine supplemented with penicillin-streptomycin (Gibco-BRL, Rockville, IN) and Fetal Bovine Serum (FBS) (Gibco-BRL, Rockville, IN) at $37^{\circ} \mathrm{C}$ in a humidified incubator with 5\% CO2. Compounds $\mathbf{A}$ and $\mathbf{B}$ were reconstituted in Dimethyl Sulfoxide (DMSO) and the final concentration of DMSO was $0.5 \%$. Compounds A and $\mathbf{B}$ were synthesized by the Medicinal Chemistry Research Laboratory at the Faculty of Pharmacy, Tehran University of Medical Sciences. Cells without treatment were considered as negative control.

\section{MTT assay}

Cell viability was determined by MTT assay. H9c2 cells were plated in 96-well plates at 7000 cells/well for $24 \mathrm{~h}$ and 5000 cells/well for $48 \mathrm{~h}$ of treatment. Cells were exposed to different concentrations of compounds $\mathbf{A}$ and $\mathbf{B}$ to reach final concentration of $0.1-100 \mu \mathrm{M}$ at 24 and $48 \mathrm{~h}$. Afterwards, $20 \mu \mathrm{l}$ of MTT (3-(4,5-dimethylthiazol-2-yl)-2,5diphenyl tetrazolium bromide, $5 \mathrm{mg} / \mathrm{ml}$ ) (Sigma-Aldrich, Saint Louis, Missouri, USA) was added for an additional 4 $\mathrm{h}$. The medium was removed and $200 \mu \mathrm{l}$ of DMSO was added to each well to dissolve formazan crystals. Finally, the absorbance was measured by microplate reader (Epoch2, Biotek, USA) at $545 \mathrm{~nm}$.

\section{Intracellular ROS determination}

To determine the intracellular ROS, H9c2 cells were seeded in 6-well plates at a concentration of $25 \times 10^{4}$ cells per well for $24 \mathrm{~h}$ and $15 \times 10^{4}$ cells for $48 \mathrm{~h}$ of incubation. Cells were then treated with 10 and $50 \mu \mathrm{M}$ of compounds A and B for 24 and $48 \mathrm{~h}$. Following incubation of cells with $10 \mu \mathrm{M}$ of DCFH (Sigma-Aldrich, Saint Louis, Missouri, USA) at $37^{\circ} \mathrm{C}$ for $20 \mathrm{~min}$, the cells were

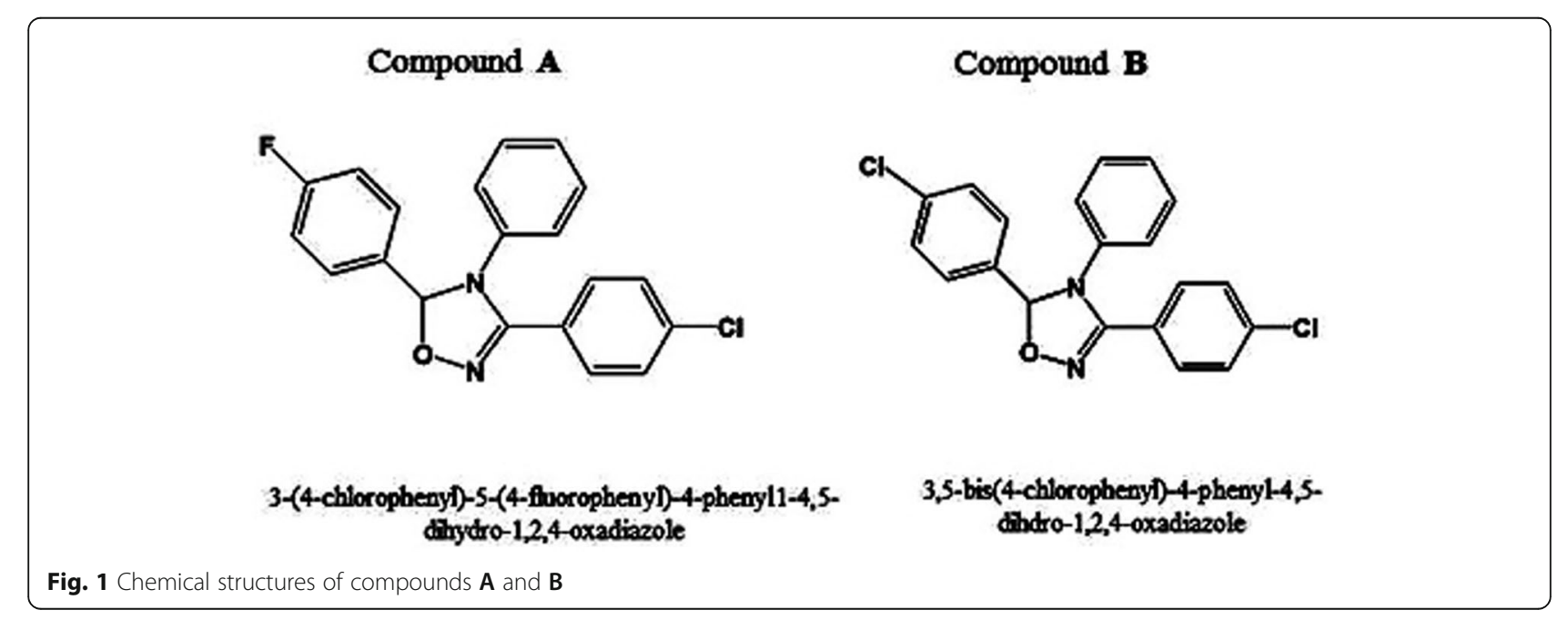


washed with PBS (Phosphate Buffered Saline) and then harvested to detect ROS level by flow cytometer.

\section{Mitochondrial membrane potential assay}

Mitochondrial dysfunction was assessed using mitochondrial membrane potential $(\Delta \Psi \mathrm{m})$ assay. Briefly, H9c2 cells were plated in 6-well plates as described above and then trypsinized after treating with 10 and $50 \mu \mathrm{M}$ of compounds A and B for 24 and $48 \mathrm{~h}$. We used carbonyl 3-chlorophenylhydrazone (CCCP) as a standard control. After washing the cells with PBS, $0.5 \mathrm{ml}$ of PBS buffer containing $10 \mu \mathrm{g} / \mathrm{ml}$ of JC-1 (Mitoprobe JC1 assay kit, Life technologies, USA, M34152) was added to the suspend cells. Following $15-30 \mathrm{~min}$ of incubation at $37^{\circ} \mathrm{C}$, cells were centrifuged to discard the supernatant. Cell pellets were then re-suspended in PBS and analyzed by flow cytometry. A mitochondria-sensitive dye (JC-1) was used to monitor mitochondrial membrane potential alterations by observing the percentage of mitochondrial matrix aggregation. The aggregate JC-1 (red fluorescence) was determined at the emission wavelength of $590 \mathrm{~nm}$, and the monomeric JC-1 (green fluorescence) monitored at $529 \mathrm{~nm}$.

\section{Apoptosis assay}

The numbers of apoptotic cells were measured by AnnexinV/PI assay kit (Roche Applied Science, Indianapolis, IN, USA) according to the manufacture's instruction. To do it, H9c2 cells were washed and then harvested after treatment with 10 and $50 \mu \mathrm{M}$ of compounds $\mathbf{A}$ and $\mathbf{B}$. Doxorubicin was used as a positive control. Next, cells were stained using $100 \mu \mathrm{l}$ of Annexin V-FLUOS labeling solution containing $2 \mu \mathrm{l}$ annexin VFLUOS labeling agent, $2 \mu \mathrm{l}$ PI solution and $1 \mathrm{ml}$ incubation buffer. Cells were then incubated for $15 \mathrm{~min}$ at $37^{\circ} \mathrm{C}$ and subjected to flow cytometry. The percentages of viable (AnnexinV-/PI-), early apoptotic (AnnexinV+/
PI-), late apoptotic (AnnexinV+/PI+) and necrotic (AnnexinV-/PI + ) cells were finally analyzed.

\section{Statistical analysis}

At least three biological replicates were considered for all experiments and the data were expressed as mean \pm SEM. To compare the differences between multiple parameters, one-way ANOVA followed by the Tukey's post test was applied using GraphPad Prism 6.0 Software. A $p$ value lower than 0.05 was considered as significant.

\section{Results}

Compounds A and B affected viability of $\mathrm{H} 9 \mathrm{c} 2$ cells

H9c2 cells were treated with different concentrations of compounds A and B for 24 and $48 \mathrm{~h}$ and cell viability was determined using MTT assay. As demonstrated in Fig. 2, both compounds reduced the cell viability in a time- and concentration-dependent manner within the concentration range of $0.1-100 \mu \mathrm{M} .75$ and $25 \mu \mathrm{M}$ concentrations of compound $\mathbf{A}$ reached the myocardial viability cells to 50.9 and $72.2 \%$, respectively, after $24 \mathrm{~h}$. These values for compound $\mathbf{B}$ were 14.9 and $58.7 \%$, which were close to their $\mathrm{IC}_{50}$ concentrations $\left(\mathrm{IC}_{50} \mathrm{~A}\right.$ : $77.02 \pm 1.09$ and $\left.\mathrm{IC}_{50} \mathrm{~B}: 28.64 \pm 1.04 \mu \mathrm{M}\right)$. The vitality of the cells was also diminished more significantly after $48 \mathrm{~h}$ of treatment compared with that of $24 \mathrm{~h}\left(\mathrm{IC}_{50-48} \mathrm{~h}\right.$ was $45.90 \pm 1.17 \mu \mathrm{M}$ for compound A vs. $10.68 \pm 1.15 \mu \mathrm{M}$ for compound $\mathbf{B}$ ). Considering our previous findings implying the effective concentration of both compounds on breast cancer cells $(\sim 10 \mu \mathrm{M})$ and that this concentration is below the $\mathrm{IC}_{50}$ values in myocardial cells, we selected $10 \mu \mathrm{M}$ for use in our following experiments. Moreover, we chose a 5-fold $\mathrm{IC}_{50}$ concentration to verify our results.

Apoptosis induction by compounds A and B in H9c2 cells Flow cytometry was applied to investigate apoptosis in the control and the compounds-treated H9c2 cells. Cell
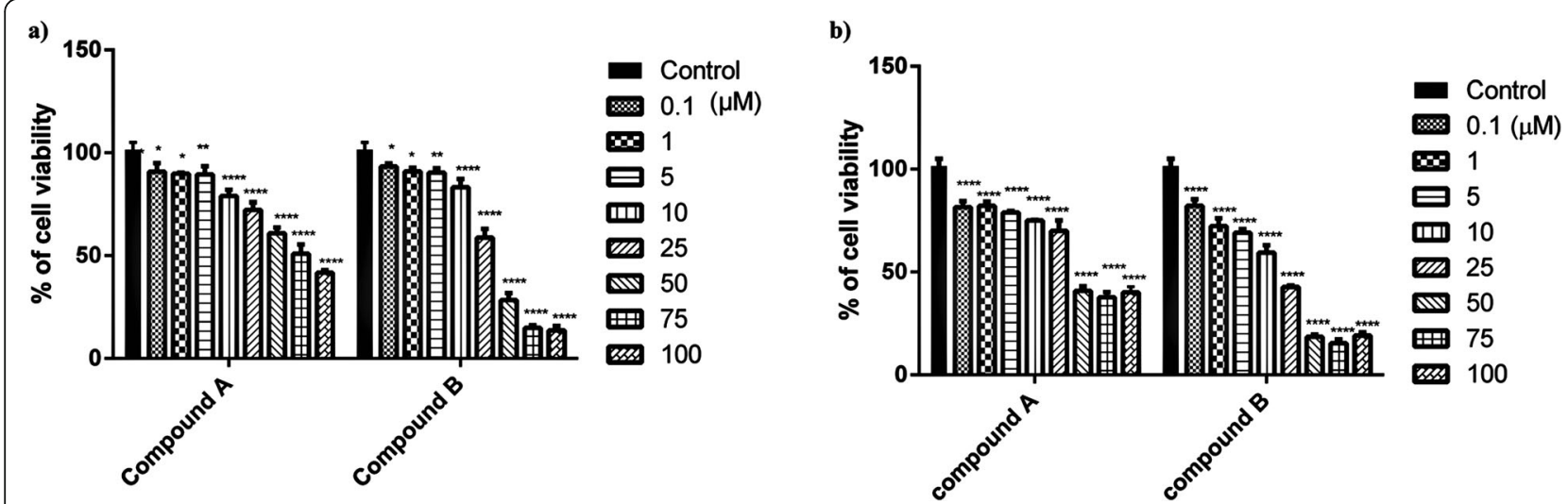

Fig. 2 Concentration-dependent cytotoxicity of compounds $\mathbf{A}$ and $\mathbf{B}$ on H9c2 cells at (a) $24 \mathrm{~h}$ and (b) $48 \mathrm{~h}$. Values are presented as mean \pm SEM of three independent experiments, performed in triplicate. $p<0.05,{ }^{* *} p<0.01,{ }^{* * *} p<0.001,{ }^{* * *} p<0.0001$ compared with control 
apoptosis was determined using Annexin V-FLUOS/Propidium iodide (PI) double staining. The apoptotic rate was concentration -dependently increased in the H9c2 cells treated with both compounds at $24 \mathrm{~h}$ compared with the control group (Fig. 3a-e). In this context, $10 \mu \mathrm{M}$ of compounds $\mathbf{A}$ and $\mathbf{B}$ did not affect the cell, while a large proportion of cells were in the early apoptotic stage when the cells were subjected to both compounds at $50 \mu \mathrm{M}$ (Table 1). Of note, no apoptotic cells were seen upon treatment of $\mathrm{H} 9 \mathrm{c} 2$ cells with $10 \mu \mathrm{M}$ of compounds $\mathbf{A}$ and $\mathbf{B}$ at $48 \mathrm{~h}$ (Fig. 3f-h and Table 1). Due to the highest rate of cell death following treating with $50 \mu \mathrm{M}$ of the compounds at $48 \mathrm{~h}$, we excluded it and focused our further experiments on $10 \mu \mathrm{M}$.

\section{Apoptosis induced by compounds A and B is through ROS generation}

Previous studies have revealed that cell apoptosis can occur as a result of ROS generation through regulation of caspase [24]. To explore whether compounds $\mathbf{A}$ and $B$ affect ROS generation at 10 and $50 \mu \mathrm{M}$ concentrations after 24 and $48 \mathrm{~h}$ of incubation, we used DCFH-DA to determine intracellular ROS level in H9c2 cells. DCFHDA freely enters the cell and is oxidized to DCF by ROS inside the cell which produces green fluorescence signals. As presented in Fig. 4a, no significant shift was seen after $24 \mathrm{~h}$ of treatment of both compounds at 10 and $50 \mu \mathrm{M}$ compared with the control group. However, an observable shift of fluorescence was detected in $\mathrm{H} 9 \mathrm{c} 2$ cells treated with $10 \mu \mathrm{M}$ of compounds $\mathbf{A}$ and $\mathbf{B}$ at $48 \mathrm{~h}$ (Fig. 4b).

\section{Compounds A and B influenced mitochondrial potential membrane}

Since mitochondrial function is highly sensitive to oxidative damages [25] and to further verify whether mitochondrial apoptosis pathway is induced by compounds $\mathbf{A}$ and $\mathbf{B}$, the mitochondrial membrane potential (MMP) was assessed using the fluorescent dye JC-1. Red fluorescence displaying the matrix of actively respiring mitochondria is the aggregate form of JC-1 molecules, while green fluorescence is emitted from the monomeric form of the JC-1 molecules indicating mitochondrial membrane depolarization. As shown in Fig. 5a, after treating with compounds $\mathbf{A}$ and $\mathbf{B}$ at $50 \mu \mathrm{M}$ for 24 , the percentage of JC-1 monomeric cells was increased compared with control, which is an indicator of the loss of MPP revealing the mitochondrial damage. No significant change was detected upon incubation of the cells with $10 \mu \mathrm{M}$ of compounds A and B for $24 \mathrm{~h}$. Similarly, no mitochondrial dysfunction was observed following treatment of the cells with both compounds at $10 \mu \mathrm{M}$ for $48 \mathrm{~h}$ (Fig. 5b).

\section{Discussion}

Evidences display that oxidative stress induces a variety of cardiomyocyte deaths, consisting of apoptosis,

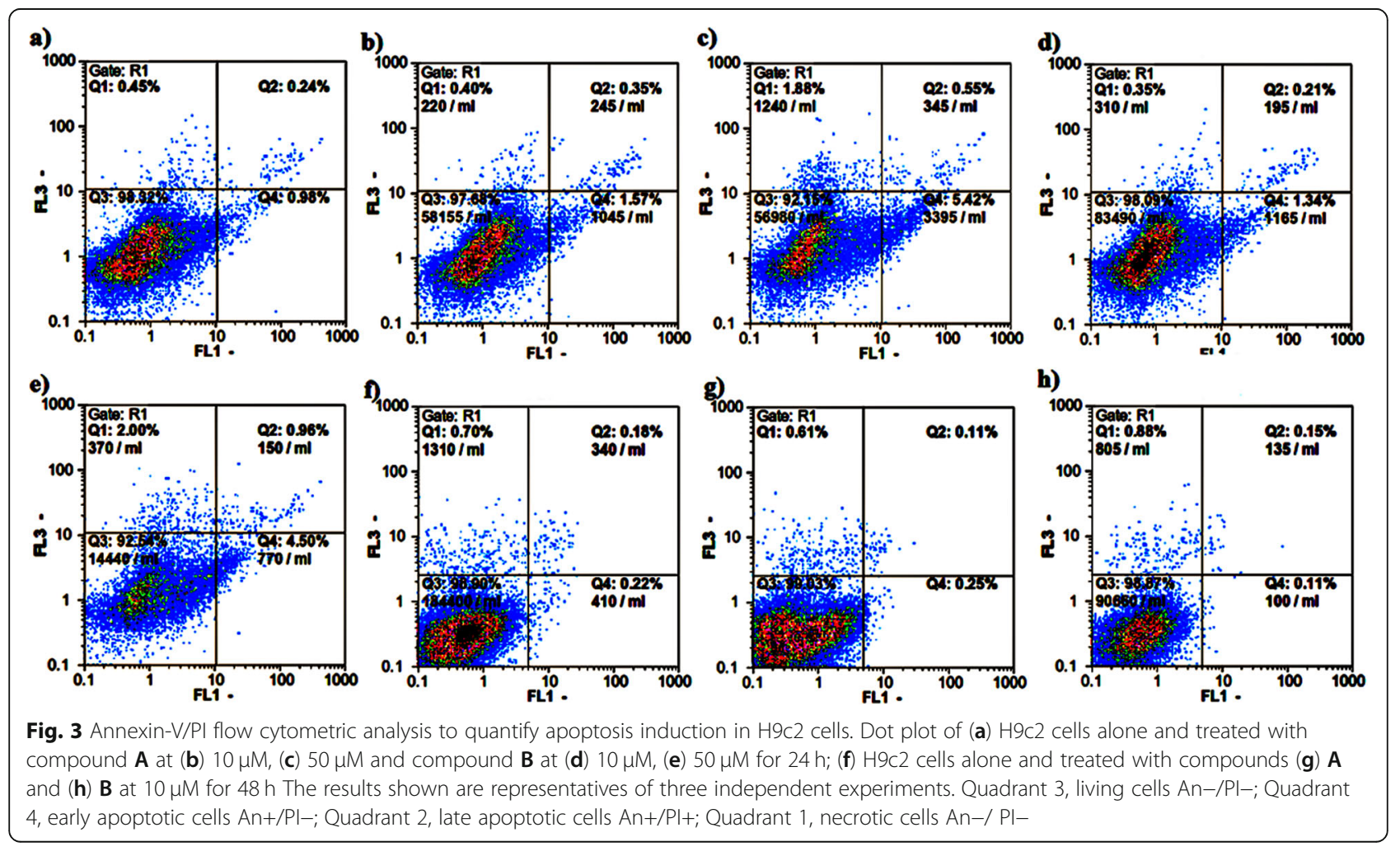


Table 1 Percentage of $\mathrm{H} 9 \mathrm{C} 2$ cells in each state after treatment with two concentrations of compounds $\mathbf{A}$ and $\mathbf{B}$ at 24 and $48 h^{\mathbf{a}}$

\begin{tabular}{|c|c|c|c|c|c|c|c|c|c|}
\hline & \multicolumn{3}{|c|}{$10 \mu \mathrm{M}(24 \mathrm{~h})$} & \multicolumn{3}{|c|}{$50 \mu \mathrm{M}(24 \mathrm{~h})$} & \multicolumn{3}{|c|}{$10 \mu \mathrm{M}(48 \mathrm{~h})$} \\
\hline & Control & Compound A & Compound B & Control & Compound A & Compound B & Control & Compound A & Compound B \\
\hline Vital cells & $97.7 \pm 0.3$ & $96.96 \pm 0.43$ & $97.83 \pm 0.25$ & $97.7 \pm 0.3$ & $92.29 \pm 0.2^{* *}$ & *** $94.11 \pm 1.5^{\star}$ & $98.88 \pm 0.01$ & $198.72 \pm 0.19$ & $98.98 \pm 0.11$ \\
\hline Early apoptosis & $1.3 \pm 0.15$ & $1.8 \pm 0.20$ & $1.1 \pm$ & $1.3 \pm 0.15$ & $5 \quad 5.3 \pm 0.52{ }^{* * * *}$ & **** $3.0 \pm 0.75^{*}$ & $0.29 \pm 0.04$ & $0.29 \pm 0.04$ & $0.08 \pm 0.02$ \\
\hline Late apoptosis & $0.3 \pm 0.07$ & $0.36 \pm 0.01$ & $0.32 \pm 0.04$ & $\mathbf{0 . 3} \pm \mathbf{0 . 0 7}$ & $0.32 \pm 0.07$ & $0.32 \pm 0.04$ & $0.16 \pm 0.2$ & $0.14 \pm 0.01$ & $0.09 \pm 0.02$ \\
\hline Necrosis & $0.24 \pm 0.06$ & $\begin{array}{ll}6 & 0.36 \pm 0.23\end{array}$ & $0.32 \pm 0.04$ & $0.24 \pm 0.06$ & 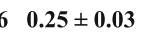 & $0.32 \pm 0.04$ & $0.66 \pm 0.02$ & $0.64 \pm 0.06$ & $0.85 \pm 0.1$ \\
\hline
\end{tabular}

The data presented are the mean \pm SEM of three independent experiments. ${ }^{*} p<0.05,{ }^{* * *} p<0.01,{ }^{* * *} p<0.001,{ }^{* * * *} P<0.0001$ compared with control

necrosis and necroptosis [26-28]. In this context, ample researches have shown that the therapeutic agents generating ROS cause cardiotoxicity [29]. Among different types of therapeutics, certain classes of chemotherapeutic agents induce more common and frequent cardiotoxic effects. On the other hand, heart dysfunction along with the promotion of cardiac hypertrophy and the loss of contractile occur due to apoptosis of cardiomyocyte, which in turn develops cardiovascular diseases [30, 31]. The anti-breast cancer activities of two novel synthesized compounds (A and B) have been previously studied [18]. Our findings revealed that these two compounds act through inducing apoptosis. Keeping in mind that apoptosis plays an important role in cardiotoxicity and in consequence heart dysfunction and knowing that these two compounds likely resemble to COX-2 inhibitors with tri-aryl structures exerting their effects via apoptosis induction [19], herein, we attempted to verify that these compounds are nontoxic to cardiac cells. Hence, we performed the in vitro experiments on $\mathrm{H} 9 \mathrm{c} 2$ cells. This is the first study to find out the effectiveness of compounds $\mathbf{A}$ and $\mathbf{B}$ to preserve the cardiomyocyte viability.

In the current study, for an exposure time of $24 \mathrm{~h}$, compounds A and B concentration-dependently decreased H9c2 cell viability. For longer period of exposure $(48 \mathrm{~h})$, these compounds also caused a decrease in cell viability implying a time -dependent cell cytotoxicity. Furthermore, our findings exhibited that the higher dose of compounds $\mathbf{A}$ and $\mathbf{B}(50 \mu \mathrm{M})$ can trigger the apoptotic process in $\mathrm{H} 9 \mathrm{c} 2$ cells upon $24 \mathrm{~h}$ of treatment in which early apoptosis to a large extent was involved in the cell death. Interestingly, a concentration of $10 \mu \mathrm{M}$ by which a remarkable anticancer activity had been seen for the compounds against breast cancer cells [18], could activate no apoptotic process at 24 and even $48 \mathrm{~h}$ on cardiac cells.

A large number of studies have elucidated that intracellular ROS generation is closely associated with cell apoptosis [32]. Consistent with the apoptosis data, our results from determining the intracellular ROS level revealed no shift in the fluorescent intensity in $\mathrm{H} 9 \mathrm{c} 2$ cells after cell exposure to $10 \mu \mathrm{M}$ of both compounds for 24 h. Surprisingly, when the cells were subjected to $50 \mu \mathrm{M}$ of compounds $\mathbf{A}$ and $\mathbf{B}$ for $24 \mathrm{~h}$, the level of ROS remained unchanged in $\mathrm{H} 9 \mathrm{c} 2$ cells which can be explained regarding the time that the ROS level was determined in the treated cells. Indeed, we assumed that following an initial increase in ROS level, it reaches the original level after $24 \mathrm{~h}$. Thus, a large population of the
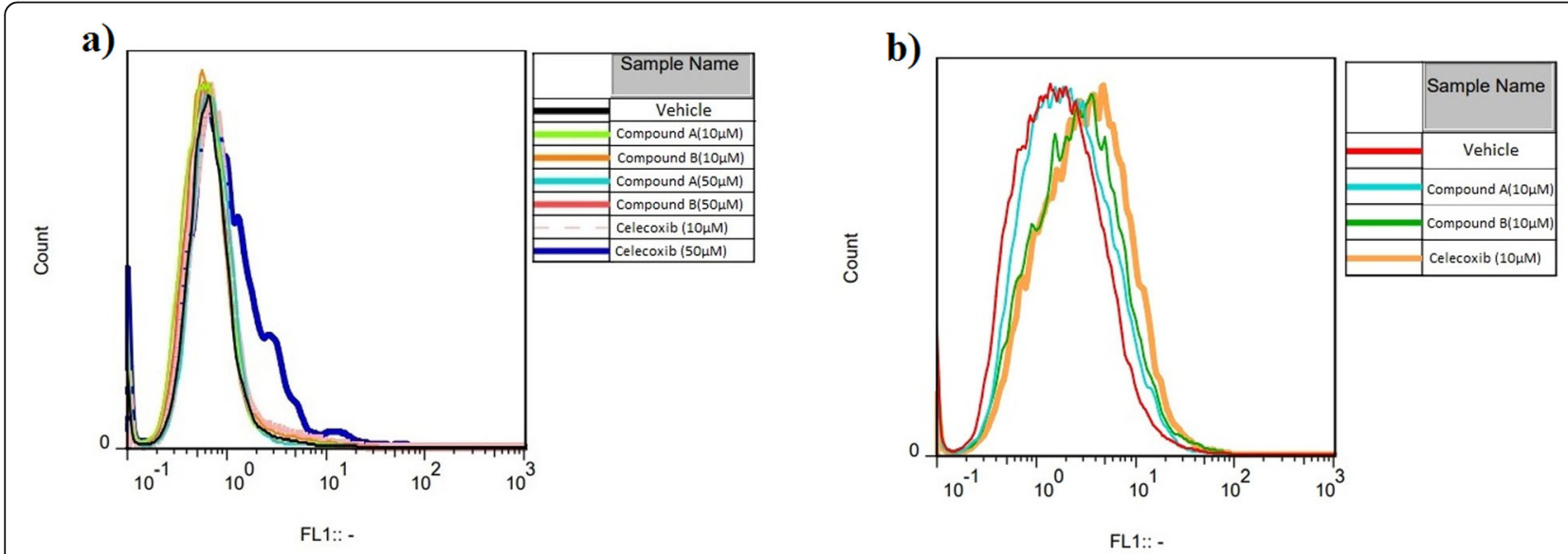

Fig. $4 \mathrm{ROS}$ generation in $\mathrm{H} 9 \mathrm{c} 2$ cells after (a) $24 \mathrm{~h}$ and (b) $48 \mathrm{~h}$. ROS was measured in the untreated H9c2 cells (control/vehicle) group as well as the cells treated with compounds $\mathbf{A}$ and $\mathbf{B}$ at 10 and $50 \mu \mathrm{M}$ 

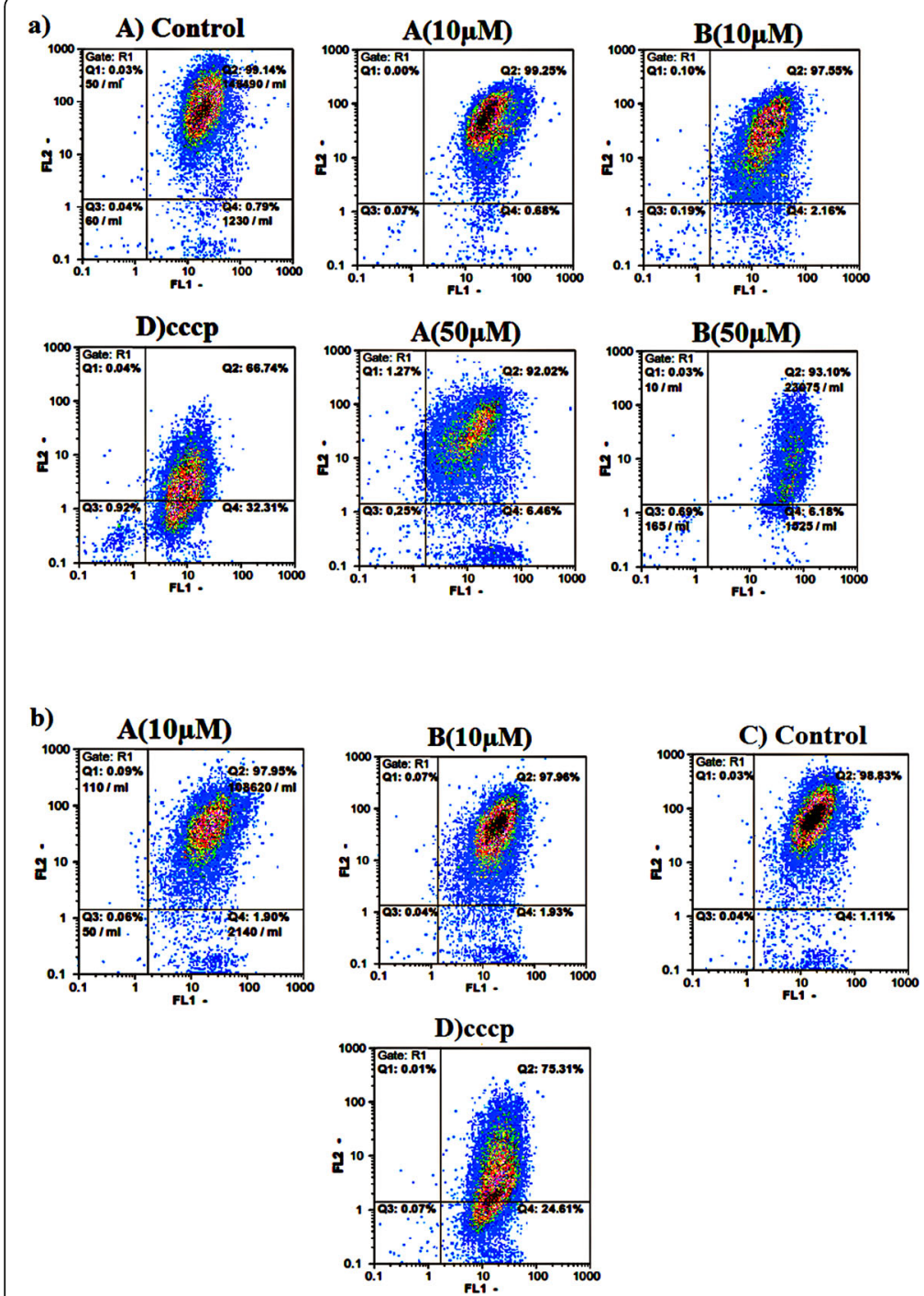

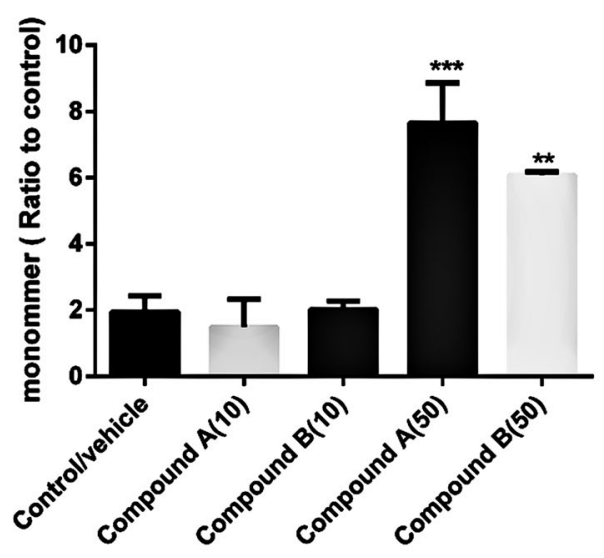

Compounds $(\mu \mathrm{M})$

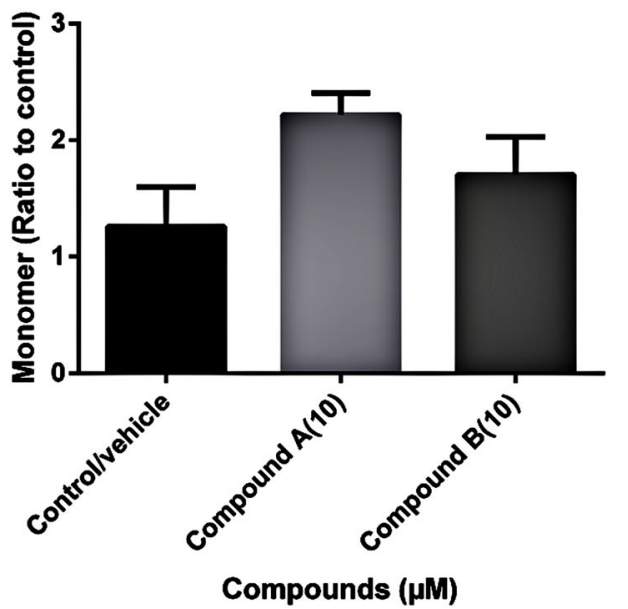

Fig. 5 a Destabilization of the mitochondrial membrane of H9c2 Cells. H9c2 cells were treated for $24 \mathrm{~h}$ with compounds $\mathbf{A}$ and $\mathbf{B}$ at 10 and 50 $\mu \mathrm{M}$, following which, they were incubated with $\mathrm{JC}-1$ mitochondrial membrane permeable dye. Fluorescence readings were obtained using image based flow cytometry; b. H9c2 cells were treated for $48 \mathrm{~h}$ with compounds $\mathbf{A}$ and $\mathbf{B}$ at $10 \mu \mathrm{M}$. Analyses were performed on 3 independent experiments and values are expressed as mean \pm SEM. ${ }^{*} p<0.01,{ }^{* * *} p<0.001$ versus vehicle/ control

cells was in the early of apoptosis at $24 \mathrm{~h}$, while no significant difference in ROS concentration was detected in the treated cells compared with the control. Moreover, after incubation of the cells with $10 \mu \mathrm{M}$ of compounds A and $\mathbf{B}$ for $48 \mathrm{~h}$, no apoptosis process was induced, whereas a small level of ROS was produced suggesting the triggering of oxidative stress which was not strong enough to induce cell apoptosis. Our data support previous findings and indicated that ROS contributes to the regulation of apoptosis but it is generated in two steps; early and late stages in which time of ROS determination plays a key role [33].

Deregulation of the different cell death pathways causes pathological outcomes for oxidative stress- associated diseases including ischemia-reperfusion injury that has to be considered as adverse effects of drugs [34]. The generated ROS can inaugurate and enhance important mitochondrial alterations by depolarizing MMP. In other words, ROS mainly causes depolarization and bulging of the mitochondria and then augments apoptotic mechanism through mitochondrial involvement $[35,36]$. Thus, as a consequence, cytochrome $c$ that is a key mediator in the mitochondrial pathway of cell death is released from mitochondria [37]. At last, upon activation of caspase-3, cell apoptosis is induced [38]. Our results demonstrated that $50 \mu \mathrm{M}$ of compounds $\mathbf{A}$ and $\mathbf{B}$ disturbed mitochondrial membrane potential $\psi \mathrm{m}$ of $\mathrm{H} 9 \mathrm{c} 2$ at $24 \mathrm{~h}$, whereas no mitochondrial 
function impairment was observed following treatment of H9c2 with $10 \mu \mathrm{M}$ of both compounds for $24 \mathrm{~h}$ confirming our apoptosis results. Interestingly, it was shown that excessive ROS can damage mitochondria as well as open its permeability transition pore (PTP), and thereby induces mitochondrial permeability transition. The mitochondrial depolarization and outer membrane rupture due to these alterations result in cell apoptosis or death $[39,40]$. These findings corroborate our obtained results and indicate that low dose of both compounds can induce ROS production after $48 \mathrm{~h}$ of treatment; however, this level of ROS was unable to induce apoptosis. Interestingly, high dose of these compounds after $24 \mathrm{~h}$ damaged mitochondrial potential and induced apoptosis, although it did not affected ROS generation suggesting an undetectable level of ROS due to the inappropriate time of measurement in the cells exposed to a high concentration of the compounds.

\section{Conclusions}

Our study represented two novel chemical molecules possessing anti-breast cancer activity with minimum influence on the oxidative stress-mediated apoptosis induction on cardiomyocytes implying therapeutic potential for heart disease. However, these compounds at the higher dose can attenuate mitochondrial dysfunction and trigger apoptosis via oxidative stress. But, the detailed mechanism of action needing to be further investigated.

\section{Abbreviations \\ CVDs: Cardiovascular diseases; ROS: Reactive oxygen species; COX- 2: Cyclooxygenase-2; MI: Myocardial infarction; DMEM: Dulbecco's modified Eagle's medium; FBS: Fetal bovine serum; DMSO: Dimethyl sulfoxide; MTT: (3- (4,5-dimethylthiazol-2-yl)-2,5-diphenyl tetrazolium bromide; DCFH: 2',7'- Dichlorofluorescin; PBS: Phosphate buffered saline; CCCP: Carbonyl 3- chlorophenylhydrazone; PI: Propidium iodide; SEM: Standard error of the mean; ANOVA: Analysis of variance; $1 \mathrm{C}_{50}$ : The half maximal inhibitory concentration; DCFH-DA: 2',7'-Dichlorofluorescin diacetate; \\ MMP: Mitochondrial membrane potential; PTP: Permeability transition pore}

\section{Acknowledgements}

Authors are thankful to the Department of Physiology and Pharmacology, Pasteur Institute of Iran for providing research facilities to prepare this valuable document.

\section{Authors' contributions}

TA and RT performed experiments. MA synthesized the chemical compounds. BD helped in designing the experiments. MS was the principle investigator who conceived the idea and helped in the preparation of the manuscript. All authors read and approved the final manuscript.

\section{Funding}

Authors are grateful to Pasteur Institute of Iran for the financial support and Tarbiat Modares University to provide the materials for this study.

\section{Availability of data and materials}

The datasets used during the present study are available from the corresponding author on reasonable request.

\section{Ethics approval and consent to participate}

There is no animal testing of the compound made in this study, and therefore, no animal ethical clearance is required for this study.

\section{Consent for publication}

Not applicable.

\section{Competing interests}

The authors declare that they have no competing interests.

\section{Author details}

'Department of Toxicology, Faculty of Medical Sciences, Tarbiat Modares University, Tehran, Iran. ${ }^{2}$ Physiology and Pharmacology Department, Pasteur Institute of Iran, P.O. Box 13164, Tehran, Iran. ${ }^{3}$ Department of Medicinal Chemistry, Faculty of Pharmacy, Tehran University of Medical Sciences, Teharn, Iran.

Received: 5 August 2020 Accepted: 2 November 2020

Published online: 19 November 2020

\section{References}

1. Heron M, Tejada-Vera B. Deaths: leading causes for 2005. Natl Vital Stat Rep. 2009;58(8):1-97.

2. Vishnu K, Kumar KA, Chatterjee NS, Lekshmi R, Sreerekha P, Mathew S, Ravishankar C. Sardine oil loaded vanillic acid grafted chitosan microparticles, a new functional food ingredient: attenuates myocardial oxidative stress and apoptosis in cardiomyoblast cell lines (H9c2). Cell Stress Chaperones. 2018;23(2):213-22.

3. Clark RA, Marin TS, Berry NM, Atherton JJ, Foote JW, Koczwara B. Cardiotoxicity and cardiovascular disease risk assessment for patients receiving breast cancer treatment. Cardiooncology. 2017;3(1):6.

4. Jain A, Rani V. Mode of treatment governs curcumin response on doxorubicininduced toxicity in cardiomyoblasts. Mol Cell Biochem. 2018;442(1-2):81-96.

5. Zamorano JL, Lancellotti P, Rodriguez Muñoz D, Aboyans V, Asteggiano R, Galderisi M, Habib G, Lenihan DJ, Lip GY, Lyon AR. 2016 ESC position paper on cancer treatments and cardiovascular toxicity developed under the auspices of the ESC Committee for practice guidelines: the task force for cancer treatments and cardiovascular toxicity of the European Society of Cardiology (ESC). Eur Heart J. 2016;37(36):2768-801.

6. Moslehi JJ, Deininger M. Tyrosine kinase inhibitor-associated cardiovascular toxicity in chronic myeloid leukemia. J Clin Oncol. 2015;33(35):4210-8.

7. Mercurio V, Pirozzi F, Lazzarini E, Marone G, Rizzo P, Agnetti G, Tocchetti CG, Ghigo A, Ameri P. Models of heart failure based on the cardiotoxicity of anticancer drugs. J Card Fail. 2016;22(6):449-58.

8. Armenian SH, Lacchetti C, Barac A, Carver J, Constine LS, Denduluri N, Dent S, Douglas PS, Durand JB, Ewer M. Prevention and monitoring of cardiac dysfunction in survivors of adult cancers: American Society of Clinical Oncology Clinical Practice Guideline. J Clin Oncol. 2017;35(8):893-911.

9. Dhingra R, Margulets V, Chowdhury SR, Thliveris J, Jassal D, Fernyhough P, Dorn GW, Kirshenbaum LA. Bnip3 mediates doxorubicin-induced cardiac myocyte necrosis and mortality through changes in mitochondrial signaling. Proc Natl Acad Sci U S A. 2014;111(51):E5537-44.

10. Galdiero MR, Varricchi G, Marone G. The immune network in thyroid cancer. Oncoimmunology. 2016;5(6):e1168556.

11. Priya LB, Baskaran R, Huang CY, Padma W. Neferine ameliorates cardiomyoblast apoptosis induced by doxorubicin: possible role in modulating NADPH oxidase/ROS-mediated NFKB redox signaling cascade. Sci Rep. 2017;7(1):1-13.

12. Varricchi G, Galdiero MR, Tocchetti CG. Cardiac toxicity of immune checkpoint inhibitors: cardio-oncology meets immunology. Circulation. 2017;136(21):1989-92.

13. Zhao L, Zhang B. Doxorubicin induces cardiotoxicity through upregulation of death receptors mediated apoptosis in cardiomyocytes. Sci Rep. 2017;7(1):1-11.

14. Biswas SK. Does the interdependence between oxidative stress and inflammation explain the antioxidant paradox? Oxid Med Cell Lingev. 2016;2016:5698931.

15. Marrison LR, Dickinson JM, Fairlamb IJ. Bioactive 4-substituted-6-methyl-2pyrones with promising cytotoxicity against A2780 and K562 cell lines. Bioorg Med Chem Lett. 2002;12(24):3509-13.

16. Shankar R, Chakravarti B, Singh US, Ansari MI, Deshpande S, Dwivedi SKD, Bid HK, Konwar R, Kharkwal G, Chandra V. Synthesis and biological evaluation of 3, 4, 6-triaryl-2-pyranones as a potential new class of antibreast cancer agents. Bioorg Med Chem. 2009;17(11):3847-56. 
17. Praveen Rao P, Amini A, Li H, Habeeb AG, Knaus EE. Design, synthesis, and biological evaluation of 6-substituted-3-(4-methanesulfonylphenyl)-4phenylpyran-2-ones: a novel class of diarylheterocyclic selective cyclooxygenase-2 inhibitors. J Med Chem. 2003;46(23):4872-82.

18. Norouzi M, Norouzi S, Amini M, Amanzadeh A, Irian S, Salimi M. Apoptotic effects of two COX-2 inhibitors on breast adenocarcinoma cells through COX-2 independent pathway. J Cell Biochem. 2015;116(1):81-90.

19. Miralinaghi P, Salimi M, Amirhamzeh A, Norouzi M, Kandelousi HM, Shafiee A, Amini M. Synthesis, molecular docking study, and anticancer activity of triaryl-1, 2, 4-oxadiazole. Med Chem Res. 2013;22(9):4253-62.

20. Shi J, Abdelwahid E, Wei L. Apoptosis in anthracycline cardiomyopathy. Curr Pediatr Rev. 2011;7(4):329-36.

21. Dorn GW. Apoptotic and non-apoptotic programmed cardiomyocyte death in ventricular remodelling. Cardiovasc Res. 2009;81(3):465-73.

22. Lee $Y$, Gustafsson AB. Role of apoptosis in cardiovascular disease. Apoptosis. 2009;14(4):536-48

23. Whelan RS, Kaplinskiy V, Kitsis RN. Cell death in the pathogenesis of heart disease: mechanisms and significance. Annu Rev Physiol. 2010;72:19-44.

24. Guo W, Liu X, Li J, Shen Y, Zhou Z, Wang M, XieY FX, Wang L, Wua X. PrdX alleviates cardiomyocyte apoptosis through ROS-activated MAPK pathway during myocardial ischemia/reperfusion injury. Int J Biol Macromol. 2018;112:608-15.

25. Zhang YE, Huang GQ, Wu B, Lin XD, Yang WZ, Ke ZY, Liu J. Hydrogen sulfide protects $\mathrm{H} 9 \mathrm{c} 2$ cardiomyoblasts against $\mathrm{H} 2 \mathrm{O} 2$-induced apoptosis. Braz J Med Biol Res. 2019;52:e7626.

26. Chen Q, Chen X, Han C, Wang Y, Huang T, Du Y, Dong Z. FGF-2 transcriptionally down-regulates the expression of BNIP3L via PI3KAAkt/ FoxO3a signaling and inhibits necrosis and mitochondrial dysfunction induced by high concentrations of hydrogen peroxide in $\mathrm{H} 9 \mathrm{c} 2$ cells. Cell Physiol Biochem. 2016;40(6):1678-91.

27. Yu Y, Sun G, Luo Y, Wang M, Chen R, Zhang J, Ai Q, Xing N, Sun X. Cardioprotective effects of Notoginsenoside R1 against ischemia/reperfusion injuries by regulating oxidative stress-and endoplasmic reticulum stressrelated signaling pathways. Sci Rep. 2016;6(1):1-14.

28. Zhang T, Zhang Y, Cui M, Jin L, Wang Y, Lv F, Liu Y, Zheng W, Shang H, Zhang J. CaMKII is a RIP3 substrate mediating ischemia-and oxidative stress-induced myocardial necroptosis. Nat Med. 2016;22(2):175-82.

29. Angsutararux P, Luanpitpong S, Issaragrisil S. Chemotherapy-induced cardiotoxicity: overview of the roles of oxidative stress. Oxid Med Cell Lingev. 2015;2015:795602.

30. Corbalan JJ, Vatner DE, Vatner SF. Myocardial apoptosis in heart disease: does the emperor have clothes? Basic Res Cardiol. 2016;111(3):31.

31. Li M, Gao P, Zhang J. Crosstalk between autophagy and apoptosis: potential and emerging therapeutic targets for cardiac diseases. Int J Mol Sci. 2016;17(3):332.

32. Liu B, Jian Z, Li Q, Li K, Wang Z, Liu L, Tang L, Yi X, Wang H, Li C. Baicalein protects human melanocytes from $\mathrm{H} 2 \mathrm{O} 2$-induced apoptosis via inhibiting mitochondria-dependent caspase activation and the p38 MAPK pathway. Free Radic Biol Med. 2012;53(2):183-93.

33. Chen Q, Chai Y, Mazumder S, Jiang C, Macklis R, Chisolm G, Almasan A. The late increase in intracellular free radical oxygen species during apoptosis is associated with cytochrome $\mathrm{c}$ release, caspase activation, and mitochondrial dysfunction. Cell Death Differ. 2003;10(3):323-34.

34. Redza-Dutordoir M, Averill-Bates DA. Activation of apoptosis signalling pathways by reactive oxygen species. Biochim Biophys Acta. 2016;1863(12):2977-92.

35. Yamamoto $\mathrm{K}$, Ichijo $\mathrm{H}$, Korsmeyer SJ. BCL-2 is phosphorylated and inactivated by an ASK1/Jun N-terminal protein kinase pathway normally activated at G2/M. Mol Cell Biol. 1992;19(12):8469-78.

36. Suhara T, Fukuo K, Sugimoto T, Morimoto S, Nakahashi T, Hata S, Shimizu M, Ogihara T. Hydrogen peroxide induces up-regulation of Fas in human endothelial cells. J Immunol. 1998;160(8):4042-7.

37. Ravagnan L, Roumier T, Kroemer G. Mitochondria, the killer organelles and their weapons. J Cell Physiol. 2002;192(2):131-7.

38. MarsdenVS, O'Connor L, O'Reilly LA, Silke J, Metcalf D, Ekert PG, Huang DC, Cecconi F, Kuida K, Tomaselli KJ. Apoptosis initiated by Bcl-2-regulated caspase activation independently of the cytochrome c/Apaf-1/caspase-9 apoptosome. Nature. 2002;419(6907):634-7.

39. Rasola A, Bernardi P. The mitochondrial permeability transition pore and its involvement in cell death and in disease pathogenesis. Apoptosis. 2007; 12(5):815-33.

40. Rannikko EH, Vesterager LB, Shaik JH, Weber SS, Cornejo Castro EM, Fog K, Jensen PH, Kahle PJ. Loss of DJ-1 protein stability and cytoprotective function by P arkinson's disease-associated proline-158 deletion. J Neurochem. 2013;125(2):314-27.

\section{Publisher's Note}

Springer Nature remains neutral with regard to jurisdictional claims in published maps and institutional affiliations.
Ready to submit your research? Choose BMC and benefit from:

- fast, convenient online submission

- thorough peer review by experienced researchers in your field

- rapid publication on acceptance

- support for research data, including large and complex data types

- gold Open Access which fosters wider collaboration and increased citations

- maximum visibility for your research: over $100 \mathrm{M}$ website views per year

At $\mathrm{BMC}$, research is always in progress.

Learn more biomedcentral.com/submissions 